\title{
Analysis of the properties of bone cement with respect to its manufacturing and typical service lifetime conditions
}

\author{
Robert Karpinski ${ }^{1, *}$, Jakub Szabelski ${ }^{1}$, Jacek Maksymiuk $^{2}$ \\ ${ }^{1}$ Lublin University of Technology, Faculty of Mechanical Engineering, Nadbystrzycka 36, 20-618 \\ Lublin, Poland \\ ${ }^{2}$ Orthopaedic Department, Łęczna Hospital, Krasnystawska 52, 21-010 Łęczna, Poland
}

\begin{abstract}
This paper analyses the impact of exposure to Ringer's solution, an isotonic solution relative to the body fluids, on the strength of bone cement. Research was conducted in order to determine moisture uptake and strength degradation. Prior to mechanical tests, the samples were seasoned in the solution simulating the human body conditions and subsequently measured to determine their increase in weight. Samples were then tested, using MTS Bionix testing system, for compressive strength according to ISO Standard. The data obtained from the measurements allowed to develop a statistical model for predicting cement absorption rate over a longer period of time. Compression strength of both seasoned and unseasoned samples was measured over time. The results were analysed statistically to show an effect of seasoning on cement strength. Cement samples show moderate moisture uptake over time, together with some decrease of compressive strength. Correlation between two above mentioned, measured factors was proven and linear model prepared. Using obtained models, one can estimate the cement strength and moisture uptake over time.
\end{abstract}

Keywords: bone cement, absorption, compression strength, statistical analysis, modelling, regression analysis

\section{Introduction}

The prevalence of degenerative bone and joint diseases is increasing at an alarming rate, in fact, in developed countries they constitute a half of all chronic diseases in patients over 50. Analysis of trends shows that the percentage of patients with degenerative bone and joint diseases is likely to double by 2020 . These conditions frequently require surgical procedures, which may include complete reconstruction of joints when their function has been lost. However, bone implants may also prove indispensable in other procedures, connected with: bone fracture, spinal problems, osteoporosis, or other conditions of human motor organs which require permanent, non-permanent or biodegradable implants. Complete or partial replacement of joint or bone tissue with orthopaedic implants may only be carried out with

\footnotetext{
* Corresponding author: r.karpinski@pollub.pl

Reviewers: František Holešovský, Augustin Görög
} 
materials capable of performing biological functions of various tissues, e.g. bones, cartilages, ligaments or tendons, and if necessary aid bone regeneration $[1,2,3]$.

\subsection{Biomaterials}

In modern dentistry and bone surgery, biomaterials, and typically cements, are commonly implemented. Surgical bone cements have found application in motor organ surgeries as a material in alloplastic joint replacement. Cements are predominantly used in alloplastic procedures of joints as a fixture for endoprosthesis, or to repair bone defects in considerable bone loss. Among other applications, the most significant ones are vertebroplasty and kyphoplasty, consisting in injecting bone cement into fractured vertebra and in fracture stabilisation.

Bone cements constitute a highly desirable material for surgeons. In surgical applications bone cements are commonly used as fixtures for hip joint endoprosthesis and to repair bone defects in considerable bone loss, in which case they are injected into the original bone. They also provide a common solution in stabilisation of knee or shoulder joint endoprosthesis, whereas low-viscosity bone cements are successfully implemented in spine surgeries following vertebral compression fracture, joining shattered bone fragments, and bone loss treatment. Their good plastic properties enable purpose-specific shaping the material in situ, to meet the demands of a particular application, providing exact filling and stable fixture of prosthesis $[3,4,5,6,7,8]$.

A healthy joint, whether hip or shoulder one, is characterised by high vibration damping capacity. In surgery, the natural structures, which have partly or fully lost their anatomical functions, are replaced by artificial components of high rigidity and low damping properties. In order to ensure that the mechanical properties of cement are not inhibited, the material must be implemented following a correct procedure and with observance of such conditions as: proper preparation (utmost accuracy in joining components), appropriate time of application (if implemented before the highly-exothermic process of polymerisation has finished, it may cause damage to tissues in the close area of application), or disruption of polymerisation by appearance of undesirable bone or fluid debris. Inhibited mechanical properties of cement may lead to complications during the procedure or loosening of the prosthesis in use $[9,10,11,12,13,14,15]$.

\section{Research Methods}

Bone cement, similarly to the majority of other polymer materials, comes into reaction with the environment, which may take the form of absorption of water or bodily fluids. In contact with cement, water will act as a plasticiser and may affect its characteristic properties [16], and therefore, bone cement must be tested in the environment resembling the human body conditions to a greatest extent. It is of utmost importance regarding long-term viscoelastic properties of cement material $[17,18]$. Our tests employed Ringer's solution, i.e. an isotonic solution, of identical osmotic potential as plasma, $1000 \mathrm{ml}$ of which contains $8.6 \mathrm{~g}$ of sodium chloride, $0.3 \mathrm{~g}$ of potassium chloride, $0.33 \mathrm{~g}$ of calcium chloride dihydrate which corresponds to the following electrolyte levels: sodium - $147 \mathrm{mmol} / \mathrm{l}$, potassium $-4 \mathrm{mmol} / \mathrm{l}$, calcium - 2.2 $\mathrm{mmol} / \mathrm{l}$, chlorides - $156 \mathrm{mmol} / \mathrm{l}$ [19]. The effect of time of immersion in Ringer's solution on compressive strength of bone cement samples was determined in physical tests, consisting of linear compressive strength tests. The samples exposed and not exposed to Ringer's solution were tested in compression upon 1, 10,20 and 30 days of seasoning in ambient temperature. The samples exposed to the solution were tested to determine the relative increase in weight, in the function of exposure time. 
The study was carried out on DePuy CMW 3 GENTAMICIN Bone Cement, containing bactericidal antibiotic, gentamicin, (Fig. 1), whose composition is shown in Table 1. The test samples were formed to desired dimensions in special moulds, which enabled producing a large number of repeatable samples. The counter-mould was designed by means of Solid Edge ST9 software, and subsequently printed with the 3D uPrint SE Plus printer with the use of durable and high-strength ABS. The proper mould was produced with POLATOSIL $®$ M33 two-component silicone rubber, by filling the counter-mould. The selection of silicone rubber as the material of the mould was dictated by the mechanical properties of rubber, which facilitate the removal of samples from the mould and enable repeated use of the mould. The dimensions and tolerance of samples were prepared according to the International Standard ISO 5388:2002, as confirmed by the measurements of finished samples. Prior to mixing the components of the bone cement, the powder and the liquid were cooled down to $16^{\circ} \mathrm{C}$ to prolong the setting time, hence enabling proper filling of moulds before cement polymerisation would start. It ought to be mentioned that in surgical practice temperature of cement is similarly reduced before its components are mixed and also during polymerisation, which is an exothermic reaction generating relatively high heat.

Table 1. Chemical composition of CMW3 GENTAMYCIN bone cement.

\begin{tabular}{|lc|}
\hline & Percentage by weight \\
\hline Bone cement powder components: & \\
Gentamicin Sulphate & 4.22 \\
Polymethyl Methacrylate & 83.88 \\
Benzoyl Peroxide & 1.90 \\
Barium Sulphate & 10.00 \\
\hline Bone cement liquid components: & \\
Methyl Methacrylate & 97.5 \\
N,N-Dimethyl-p-toluidine & $<2.50$ \\
Hydroquinone & $75 \mathrm{ppm}$ \\
\hline
\end{tabular}

The compression strength tests were carried out on a custom-built test stand, consisting of: MTS Bionix - Servohydraulic Test System for biomedical applications, and special instrumentation in the form of customised grips. The MTS TestWorks software was used to programme and perform the experiment. Compression strength test parameters, including compression time and rate, were specified in accordance with the ISO standard.

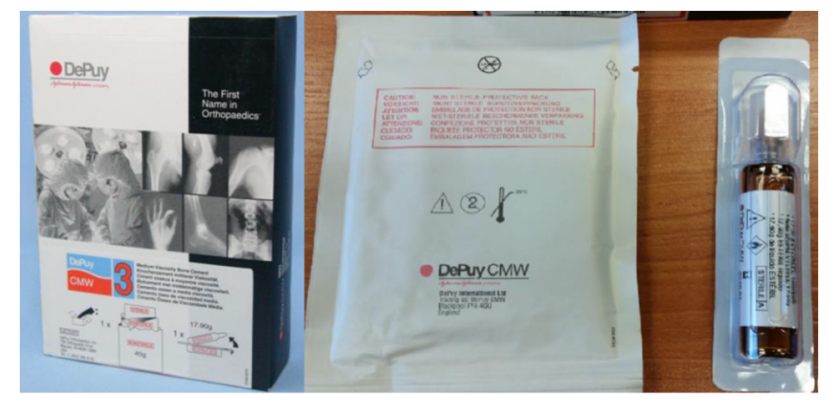

Fig. 1. CMW3 GENTAMYCIN bone cement by DePuy CMW

\section{Moisture Uptake}

Mean weight increase of cement samples as a result of moisture uptake from Ringer's solution was estimated by weighing the entire sample lots prior to and after exposure to the 
solution. The samples prior to weighing were gently wiped to remove potential micro drops off the surface of samples. As anticipated, progressing absorption processes led to weight increase of samples. Table 2 shows relative mean weight increase of cement material in the function of time of exposure to Ringer's solution.

Table 2. Relative mean weight increase of cement after exposure to Ringer's solution.

\begin{tabular}{|c|c|c|c|}
\hline $\begin{array}{c}\text { Seasoning } \\
\text { time } \\
\text { [days] }\end{array}$ & $\begin{array}{c}\text { Mean weight of } \\
\text { unseasoned samples } \\
{[\mathrm{g}]}\end{array}$ & $\begin{array}{c}\text { Mean weight } \\
\text { increase of samples } \\
{[\mathrm{g}]}\end{array}$ & $\begin{array}{c}\text { Relative weight } \\
\text { increase of samples } \\
{[\%]}\end{array}$ \\
\hline 1 & 0.358 & 0.0020 & $0.6 \%$ \\
\hline 10 & 0.354 & 0.0075 & $2.1 \%$ \\
\hline 20 & 0.348 & 0.0089 & $2.6 \%$ \\
\hline 30 & 0.351 & 0.0110 & $3.1 \%$ \\
\hline
\end{tabular}

To provide the best fit of the mathematical model to the results from the tests, the data was analysed statistically in order to establish qualitative coefficients of determination. As it was only the logarithmic model that was suitable for the purpose of describing diffusion in porous media, it was resolved that this would be the model analysed. Fig. 2 and Table 3 show the results of the analyses.

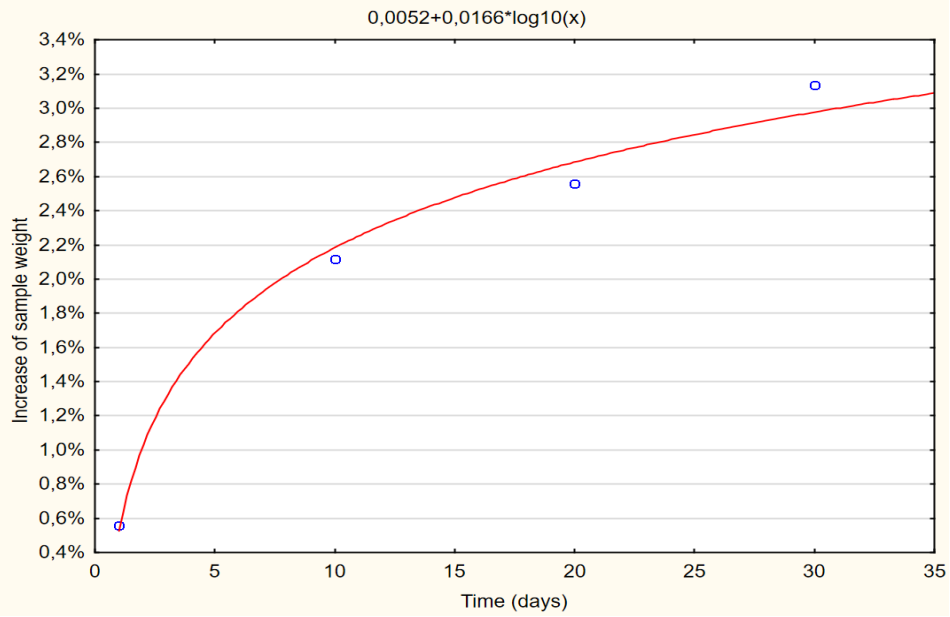

Fig. 2. Increase of sample weight over time

The conducted statistical analysis of the data obtained from the study and the verification of the adjusted model in the form of the equation: weight $=0.52 \%+1.66 \% \cdot \log 10$ (time), indicate a good fit of the model (Fig. 2). The p-value for test $F<\alpha=0.05$, therefore the regression equation is significant. The correlation coefficient $\mathrm{R}=0.993$ indicates a strong correlation between the variables. Coefficient of determination R2 explains the weight increase of seasoned samples in $98 \%$.

The developed model was employed to project the weight increase of samples in the subsequent days. The estimated results are shown in Table 3 below. 
Table 3. Projected weight increase of bone cement samples.

\begin{tabular}{|c|c|}
\hline $\begin{array}{c}\text { Seasoning time } \\
\text { [days] }\end{array}$ & $\begin{array}{c}\text { Estimated weight } \\
\text { increase [\%] }\end{array}$ \\
\hline 40 & $3.2 \%$ \\
\hline 60 & $3.5 \%$ \\
\hline 100 & $3.8 \%$ \\
\hline 200 & $4.3 \%$ \\
\hline
\end{tabular}

The logarithmic character of weight increase in samples suggests that the liquid absorption rate is the highest at the beginning of seasoning and decreases over time.

\section{Compression Strength}

Bone cement samples seasoned in Ringer's solution were subjected to static compression tests, mean results are shown in Table 4.

Table 4. Test results

\begin{tabular}{|c|c|c|c|}
\hline $\begin{array}{c}\text { Seasoning } \\
\text { time } \\
{[\text { days] }}\end{array}$ & $\begin{array}{c}\text { Compression } \\
\text { strength } \\
{[\mathrm{MPa}]}\end{array}$ & $\begin{array}{c}\text { Standard } \\
\text { deviation } \\
{[\mathrm{MPa}]}\end{array}$ & $\begin{array}{c}\text { Coefficient of } \\
\text { variation } \\
{[\%]}\end{array}$ \\
\hline 0 & 73.88 & 3.91 & $5.3 \%$ \\
\hline 1 & 71.10 & 3.96 & $5.6 \%$ \\
\hline 10 & 69.06 & 3.66 & $5.3 \%$ \\
\hline 20 & 63.68 & 2.93 & $4.6 \%$ \\
\hline 30 & 64.28 & 3.17 & $4.9 \%$ \\
\hline
\end{tabular}

Based on statistical analysis of compression strength test results for cement samples, it was observed that all values were of normal distribution (for the Kolmogorov-Smirnov, Lilliefors and Shapiro-Wilk tests $\mathrm{p}>\alpha=0.05$ ) (Tab.5.). There is no reason to reject the hypothesis of the normal distribution of the obtained results, which makes it possible to employ t-Student tests to evaluate the differences between mean results (Table 6)

Table 5. Normal distribution test result: $\max \mathrm{D}$ - max. D value for Lillefors test, K-S p - Kolmogorov-Smirnov test, Lillef p. - Lillefors test, W - Shapiro-Wilk test, $\mathrm{p}$ - $\mathrm{p}$ value for Shapiro-Wilk test).

\begin{tabular}{|c|c|c|c|c|c|}
\hline $\begin{array}{c}\text { Seasoning } \\
\text { time }\end{array}$ & $\max \mathbf{D}$ & $\begin{array}{c}\text { K-S } \\
\mathbf{p}\end{array}$ & $\begin{array}{c}\text { Lillief. } \\
\mathbf{P}\end{array}$ & $\mathbf{W}$ & $\mathbf{p}$ \\
\hline 0 days & 0.214150 & $\mathrm{p}>.20$ & $\mathrm{p}>.20$ & 0.926018 & 0.549718 \\
\hline 1 day & 0.164024 & $\mathrm{p}>.20$ & $\mathrm{p}>.20$ & 0.930915 & 0.456951 \\
\hline 10 days & 0.159465 & $\mathrm{p}>.20$ & $\mathrm{p}>.20$ & 0.929232 & 0.440382 \\
\hline 20 days & 0.165803 & $\mathrm{p}>.20$ & $\mathrm{p}>.20$ & 0.949603 & 0.707229 \\
\hline 30 days & 0.134917 & $\mathrm{p}>.20$ & $\mathrm{p}>.20$ & 0.969350 & 0.884752 \\
\hline
\end{tabular}


Table 6. Testing for differences between mean values

\begin{tabular}{|c|c|c|c|c|c|c|}
\hline & \multicolumn{2}{|c|}{ Tests for equality of variances } & \multicolumn{3}{|c|}{ Test for equality of means } \\
\hline $\begin{array}{c}\text { Samples acc. to } \\
\text { seasoning time } \\
\text { [days] }\end{array}$ & $\begin{array}{c}\text { P } \\
\text { F test }\end{array}$ & $\begin{array}{c}\text { P } \\
\text { Levene }\end{array}$ & $\begin{array}{c}\text { P } \\
\text { Brn-Fors }\end{array}$ & \multicolumn{3}{|c|}{$\begin{array}{c}\text { P } \\
\text { Cochran-Cox }\end{array}$} \\
\hline$\underline{0-1}$ & 0.737 & 0.974 & 0.971 & 0.122 & $>\alpha(0.05)$ & non-significant difference \\
\hline $0-10$ & 0.433 & 0.571 & 0.569 & 0.048 & $<\alpha(0.05)$ & significant difference \\
\hline $0-20$ & 0.488 & 0.720 & 0.714 & 0.001 & $<\alpha(0.05)$ & significant difference \\
\hline $0-30$ & 0.215 & 0.494 & 0.512 & 0.001 & $<\alpha(0.05)$ & significant difference \\
\hline$\underline{1-10}$ & 0.105 & 0.286 & 0.310 & 0.781 & $>\alpha(0.05)$ & non-significant difference \\
\hline $1-20$ & 0.102 & 0.320 & 0.352 & 0.015 & $<\alpha(0.05)$ & significant difference \\
\hline $1-30$ & 0.593 & 0.433 & 0.501 & 0.025 & $<\alpha(0.05)$ & significant difference \\
\hline $10-20$ & 0.677 & 0.607 & 0.682 & 0.005 & $<\alpha(0.05)$ & significant difference \\
\hline $10-30$ & 0.879 & 0.737 & 0.732 & 0.008 & $<\alpha(0.05)$ & significant difference \\
\hline$\underline{20-30}$ & 0.737 & 0.974 & 0.971 & 0.700 & $>\alpha(0.05)$ & non-significant difference \\
\hline
\end{tabular}

According to results obtained from statistical analyses regarding the mean values equality the following chart, presenting overall test results, was prepared (Fig.3).

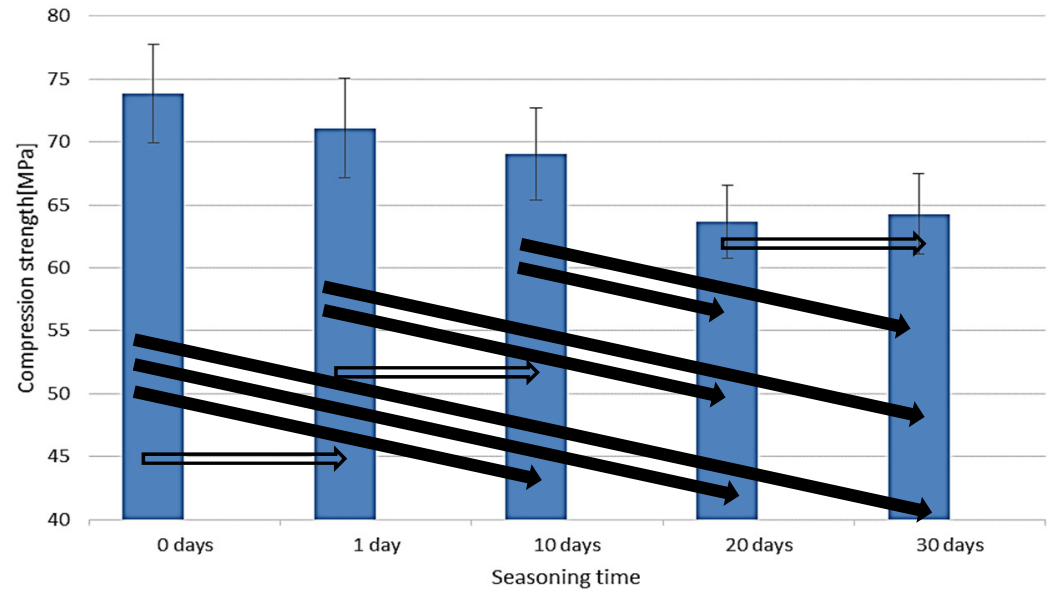

Fig. 3. Equality of mean values of compression strength after seasoning

The results of tests conducted on seasoned bone cement samples lead to the following observations:

- often comparison of strength test results for cements between two consecutive series show no statistically significant differences between the strength of either of cement sample, see: $0-1$ day, $1-10$ days, $20-30$ days.

- however statistical analysis of strength test results shows substantial differences between series of samples when comparing wider combinations of seasoning time, for example between 0 days and 10 days, etc.

- following the analysis of obtained values, at a standard significance level $(\alpha=0.05)$, for consecutive sample series, arrows were placed in Fig. 3 to illustrate the change. In 
the case of no substantial differences, the arrows between the bars representing consecutive series were horizontal, decreasing strength was represented by $\underline{\text { solid }}$ arrow.

\section{Conclusions}

The results of tests determining weight increase of bone cement samples exposed to Ringer's solution (Fig 2, Tab. 2-3) show the rise in the weight of samples over the seasoning time. The statistical part of tests was conducted by means of Statistica 13.1 software. The statistical results allowed us to obtain a mathematical model that showed good fit with the results of the data from the compression strength tests, and the data found in relevant literature as well as from logarithmic models for porous media moisture uptake. The model was subsequently verified to show the certainty level of $\mathrm{R}^{2}=98 \%$.

The statistical software was used to analyse and correlate individual sample lots, accounting for the coefficient of variation of the lots. The coefficient of variation for all analysed sample lots was in the range of $4.5 \%$ and $5.6 \%$, hence indicating low variance of results according to accepted criteria. The statistical analysis of compression strength of bone cement samples relative to the seasoning time in Ringer's solution, carried out at the specified level of significance, showed that the highest disparity between the sample lots was observed for samples not exposed to Ringer's solution and samples seasoned for at least 1 day. The difference between the sample lots analysed after subsequent periods of time showed a general tendency for samples seasoned for a shorter time to develop higher mean strength. Maximum mean compression strength was observed in samples that were not exposed to Ringer's solution, amounting to $73.88 \mathrm{MPa}$. The results of statistical analysis show decline in strength of the samples in almost all analysed sample lots, i.e. after 10, 20 and 30-day exposure. What is more, significant differences were shown in compression strength between samples after 1-day and 20-day and 30-day exposure to the solution. The lowest observed strength of samples was recorded after 20-day exposure (63.68 MPa). The analysis of results indicates that the time of the study could have been extended as the samples analysed in subsequent periods of time (e.g. 1-10 days or 20-30 days) did not show statistical differences.

The lack of correlation between our results and the data provided by the manufacturer may be explained by the fact that in our study the samples were prepared, stored, seasoned in Ringer's solution, and tested in normal conditions, i.e. at $22^{\circ} \mathrm{C}$. The real conditions of their operation $\left(37^{\circ} \mathrm{C}\right.$ and slightly different environment) were not represented. However, it was shown that the created conditions do affect the mechanical properties of bone cements: the presence of bodily fluids has a negative effect on the mechanical characteristics of cement. One relevant finding of the study is that in certain conditions cements did not exhibit the limit of the compression strength of materials for clinical applications, $66.3 \mathrm{MPa}$, as specified by the standard (ISO 5833:2002). Nevertheless, in the majority of tests the bone cement samples exhibited sufficient strength.

The analysis of correlation between the results obtained from the study, i.e. the weight increase of cement samples seasoned in Ringer's solution and the mean compression strength of these samples, provides an $88 \%$ explanation for the aforementioned relationship by means of the following linear model: strength=73.561-308.55*weight_increase (Fig.4). 


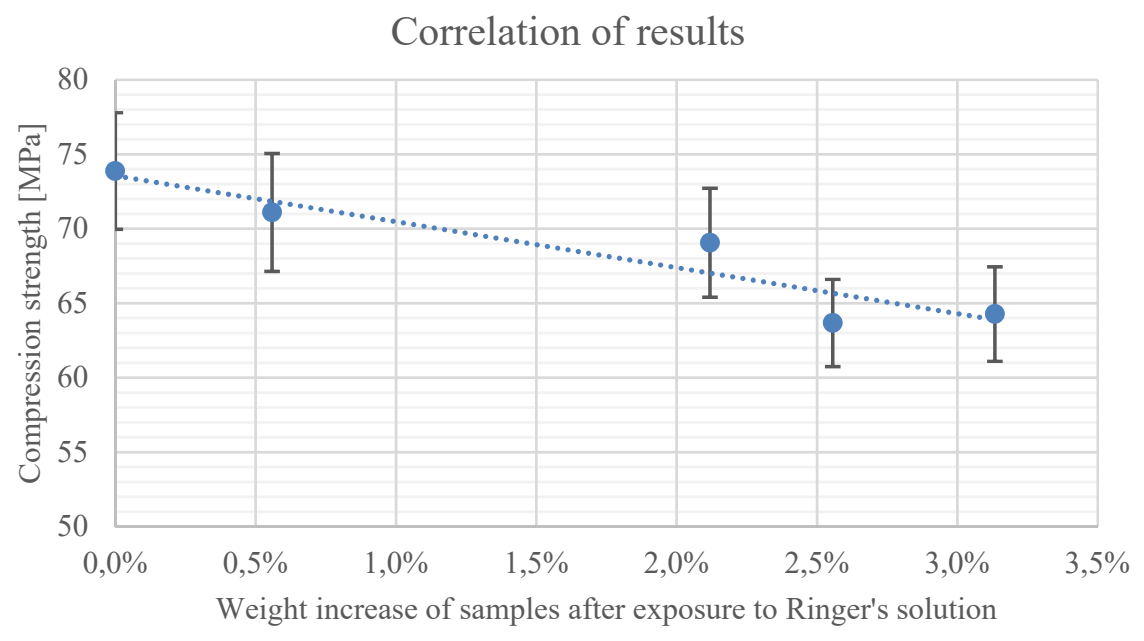

Fig. 4. Correlation between the weight increase of cement samples seasoned in Ringer's solution and the mean compression strength of samples

Thus developed model is prepared for further analysis into the strength behaviour of cement absorbing water; furthermore, if supplemented by the model of absorption in time, it may be employed to estimate strength of cement over time, which suggests direction for future research.

Bone cements are crucial in modern orthopaedics. The mechanical characteristics of these biomaterials require further exploration, and therefore future studies are recommended in order to determine the strength of cement in the presence of physiological fluid debris injected into the material, as well as the impact of elevated human body temperature conditions (approx. $37^{\circ} \mathrm{C}$ ).

\section{References}

1. R. Karpiński, Ł. Jaworski, J. Zubrzycki, Structural analysis of articular cartilage of the hip joint using finite element method. Advances in Science and Technology Research Journal (2016)

2. J. Zubrzycki, R. Karpinski, L. Jaworski, A.M. Ausiyevich, N. Smidova, Structural analysis of the pelvic girdle before and after hip replacement procedure. Science \& Technique. 17(2), 165-172 (2018) [on line - https://doi.org/10.21122/2227-10312018-17-2-165-172]

3. M. Navarro, A. Michiardi, O. Castano, J. A. Planell, Biomaterials in orthopaedics. Journal of the Royal Society Interface, 5(27), 1137-1158 (2008)

4. S. Błażewicz, L. Stoch, Biomateriaty. Warszawa, Akademicka Oficyna Wydawnicza Exit (2003)

5. M. Nałęcz, H. Kuś, Wydawnictwa Komunikacji i Łaczności, eds. Problemy biocybernetyki i inżynierii biomedycznej. Biomateriały, Wydawnictwa Komunikacji i Łączności (1990)

6. S. R. Knight, R. Aujla, S. P. Biswas, Total hip arthroplasty-over 100 years of operative history. Orthopedic reviews, 3(2), 16. (2011) 
7. J. Caban, R. Karpiński, D. Barta, Road traffic accident injuries-Causes and biomaterial related treatment. Automotive Safety, 2018 XI International ScienceTechnical Conference, 1-7 (2018)

8. A., Massazza, G., Verné, E., Massè, A., Deledda, D., Ferraris, S. ... \& Crova, M. Antibiotic-loaded cement in orthopedic surgery: a review. ISRN orthopaedics (2011)

9. H. Lelovics, T. Liptakova, Time and mixing techniquedependent changes in bone cement SmartSet (R) HV. Acta of bioengineering and biomechanics. 1;12(4):63-7 (2010)

10. T. Liptáková, H. Lelovics, L. Necas, Variations of temperature of acrylic bone cements prepared by hand and vacuum mixing during their polymerization. Acta Bioeng Biomech. 1;11:47-51 (2009)

11. H. Lelovics, T. Liptáková, Comparison of some mechanical and rheological properties of bone cements. 25th Danubia - Adria Symposium on Advances in Experimental Mechanics, Czech Republic, 157-158 (2008)

12. R. Vaishya, M. Chauhan, A. Vaish, Bone cement. Journal of Clinical Orthopaedics and Trauma, 4(4), 157-163 (2013), http://doi.org/10.1016/j.jcot.2013.11.005

13. M. Sarlinova, E. Halasova, P. Palcek, R. Seewald, Fracture properties of bone cements. ELEKTRO, 616-620 (2014)

14. P. Pétursson, K. J. Edmunds, M. K. Gíslason, B. Magnússon, G. Magnúsdóttir, G. Halldórsson,... \& P. Gargiulo, Bone mineral density and fracture risk assessment to optimize prosthesis selection in total hip replacement. Computational and mathematical methods in medicine (2015)

15. P. Gargiulo, T. Pétursson, B. Magnússon, P. Bifulco, M. Cesarelli, G. M. Izzo,... \& H. Jónsson, Assessment of total hip arthroplasty by means of computed tomography $3 D$ models and fracture risk evaluation. Artificial organs, 37(6), 567-573. (2013)

16. A.J.C Lee, R.S.M Ling, S.S Vangala, Some clinically relevant variables affecting the mechanical behavior of bone cement. Arch Orthop Traumat Surg, 92: 1-18 (1978)

17. A.J.C Lee, R.S.M Ling, S. Gheduzzi, J-P Simon, R.J. Renfro. Factors affecting the mechanical and viscoelastic properties of acrylic bone cement. J Mater Sci - Mater in med., 13: $723-733$ (2002)

18. A.J.C. Lee, The mechanical properties of recovered PMMA bone cement. Hip International 2004; 142 p.79 (2004)

19. R. Karpiński, J. Szabelski, J. Maksymiuk, Effect of Ringer's Solution on Tensile Strength of Non-Absorbable, Medium-and Long-Term Absorbable Sutures. Advances in Science and Technology. Research Journal, 11/4, (2017) 